\title{
PENINGKATAN PRESTASI/NILAI PESERTA DIDIK TOPIK PRODUKTIFITAS MELALUI TEKNIK TES UNJUK KERJA
}

\author{
Endang Suasaningdyah \\ (SMP Negeri 33 Surabaya, email : endangsdyah@yahoo.co.id)
}

\begin{abstract}
Abstrak
Tujuan dalam penelitian ini yaitu untuk meningkatkan prestasi/nilai peserta didik dalam menguasai mata pelajaran IPS topik produktifitas, mengetahui faktor-faktor yang mempengaruhi pelaksanaannya. Jenis penelitian ini adalah Penelitian Tindakan Kelas. Subyek penelitiannya adalah peserta didik kelas VII E SMPN 33 Surabaya semester genap Tahun Pelajaran 2006 - 2007 yang berjumlah 38, dan obyek penelitiannya adalah nilai yang diperoleh setelah melakukan unjuk kerja. Prosedur yang dilakukan terbagi dalam bentuk siklus I dan siklus II, setiap siklus terdiri atas perencanaan, tindakan pelaksanaan, pengamatan dan refleksi. Analisis yang digunakan analisis deskriptif kualitatif. Hipotesis yang diajukan yaitu, teknik tes unjuk kerja dapat meningkatkan prestasi/nilai peserta didik dalam menguasai mata pelajaran IPS topik produktifitas di kelas VII E SMPN 33 Surabaya. Hasil analisis terhadap nilai siswa Siklus I rata-rata 72,95. Siklus II rata-rata 79,21. Nilai peserta didik setelah mengalami 2 siklus tetap tinggi, walaupun dilakukan perubahan spesialisasi kerja, serta merubah skor dari hasil produksi dibagi 2 menjadi dibagi 4 pada putaran 3 siklus II. Berdasarkan hasil penelitian ini, melalui teknik tes unjuk kerja dapat meningkatkan prestasi/nilai peserta didik sehingga hipotesa dapat diterima.
\end{abstract}

Kata Kunci: Prestasi/Nilai, Aktivitas peserta didik, Unjuk kerja

\section{Abstract}

The purpose of this research is to improve the performance/ score learners in mastering the social studies topic of productivity, determine the factors that affect its implementation. This research is a classroom action research. The subject of the study was the students of class VII E SMPN 33 Surabaya which totaled 38 , and the object of research is the value obtained after the performance. The procedures performed are divided in the form of the first cycle and the second cycle, each cycle consisting of planning, action implementation, observation and reflection. The analysis used descriptive qualitative analysis. The proposed hypothesis, namely, engineering test performance can improve the performance/ score learners in mastering the social studies topic of productivity in class VII E SMPN 33 Surabaya. Analysis of the first cycle students score an average of 72.95. Cycle II average of 79.21. Score learners having experienced two cycles remain high, despite the work done specialties change, and change scores of production divided by 2 into a divided four on lap 3 the second cycle. Based on these results, through the performance test techniques can improve the performance/ score learners so that the hypothesis can be accepted.

Keywords: Achievement/score, activities learners, performance

\section{PENDAHULUAN}

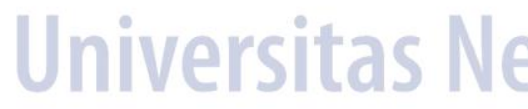

Pembelajaran adalah proses interaksi antara peserta didik dengan lingkungannya sehingga terjadi perubahan perilaku kearah yang lebih baik. Dalam pembelajaran tugas guru yang paling utama adalah mengkondisikan lingkungan agar menunjang terjadinya perubahan perilaku bagi peserta didik. Untuk mengkondisikan lingkungan tersebut, dalam membuat desain pembelajaran sekurang-kurangnya mencakup tiga hal yaitu tujuan, strategi dan sistem penilaian. Sistem penilaian merupakan seperangkat teknik untuk mengukur tingkat pencapaian kompetensi yang direncanakan. Alat ukur yang baik harus dapat mengungkap hasil penguasaan kompetensi baik/pada aspek intelektual, sikap maupun perilaku. Penguasaan kompetensi dapat dilihat dari seberapa banyak indikator kemampuan dasar yang muncul ketika di evaluasi. Sistem penilaian dalam pembelajaran mata pelajaran IPS adalah serangkaian kegiatan untuk memperoleh, menganalisis dan menafsirkan data tentang proses dan hasil belajar peserta didik yang dilakukan secara sistematis dan berkesinambungan, sehingga menjadi informasi yang bermakna dalam pengambilan keputusan pembelajaran. Sedangkan alat ukur yang digunakan untuk mengumpulkan data dalam penilaian dapat berbentuk tes dan non tes. 
Dalam mata pelajaran IPS guru seringkali kesulitan untuk mencari teknik penilaian apa yang cocok digunakan supaya nilai semua aspek yang didapat peserta didik diatas KKM (kriteria ketuntasan minimal). Untuk nilai aspek koqnitif peserta didik bisa mendapat nilai diatas KKM, tetapi apakah nilai aspek afektif dan psikomotor bisa sama atau diatas KKM? hal inilah yang sering tidak disadari oleh guru dalam menilai kemampuan peserta didik. Masalah lain yaitu, guru terlalu terpaku pada nilai KKS (kumpulan kegiatan siswa), nilai ulangan harian dan nilai ulangan akhir semester, yang diasumsikan ketiga nilai tersebut sudah mewakili kemampuan prestasi peserta didik secara proporsional, padahal ketiga nilai tersebut tidak bisa dijadikan tolok ukur untuk menilai kemampuan peserta didik, karena hanya mengukur kemampuan peserta didik dalam aspek koqnitif saja. Dalam mata pelajaran IPS topik produktifitas guru sering terpaku pada penilaian yang hanya berbentuk tes dan mengabaikan penilaian berbentuk non tes, padahal penilaian dalam bentuk non tes dapat mengetahui kemampuan peserta didik yang menyangkut aspek sosial, emosional, spiritual, kreatifitas dan moral. Solusi untuk memecahkan masalah tersebut yaitu diperlukan teknik tes unjuk kerja yang dapat menilai kemampuan anak didik dalam berbagai aspek.

Teknik tes unjuk kerja topik produktifitas merupakan teknik penilaian yang dilakukan dengan mengamati kegiatan peserta didik dalam melakukan tugas membuat buku tulis kecil (menyerupai buku tulis) dengan mempertimbangkan: (1) Langkah-langkah kinerja yang dilakukan peserta didik dalam membuat buku tulis, (2) Kelengkapan dan ketepatan aspek yang akan dinilai dalam membuat buku tulis, (3) Kemampuankemampuan khusus yang diperlukan untuk menyelesaikan tugas membuat buku tulis. Dengan melakukan kegiatan ini, peserta didik mengetahui kekuatan dan kelemahan dalam proses pencapaian kompetensinya, sehingga termotivasi untuk memperbaiki hasil belajarnya dalam suasana yang rileks dan menyenangkan.

Permasalahan : (1) Bagaimanakah peningkatan prestasi/nilai peserta didik dalam menguasai mata pelajaran IPS topik produktifitas setelah menggunakan teknik tes unjuk kerja?, (2) Faktor apa sajakah yang mempengaruhi pelaksanaan teknik tes unjuk kerja dalam rangka meningkatkan prestasi/nilai peserta didik dalam menguasai mata pelajaran IPS topik produktifitas?

Tujuan Penelitian : (1) Mengetahui apakah ada peningkatan prestasi/nilai peserta didik dalam menguasai mata pelajaran IPS topik produktifitas setelah menggunakan teknik tes unjuk kerja, (2) Mengetahaui apakah faktor-faktor yang mempengaruhi pelaksanaan teknik tes unjuk kerja dalam rangka meningkatkan prestasi/nilai peserta didik dalam menguasai mata pelajaran IPS topik produktifitas.

\section{METODE}

Desain penelitian mengikuti desain model Lewin yang ditafsirkan oleh Rochiati Wiraatmadja (Mulyasa, 2009: 182)

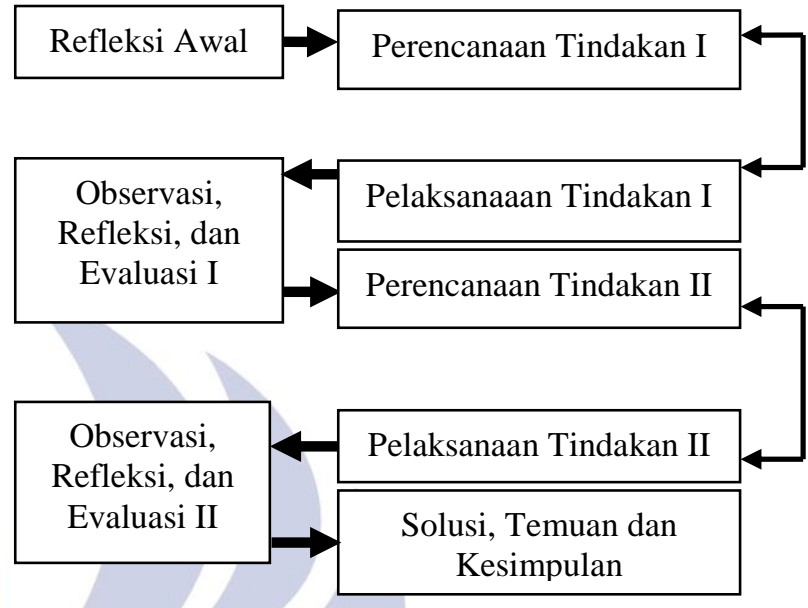

Gambar 1. Desain Penelitian Model Lewin

Berdasarkan gambar 1, tahapan penelitian dijelaskan sebagai berikut: (1) .Refleksi Awal. Pada tahap ini dilakukan identifikasi kesulitan peserta didik dalam memahami konsep dasar produktifitas, (2) Perencanaan Tindakan. Masalah yang ditemukan pada refleksi awal akan diatasi dengan melakukan langkah-langkah perencanaan tindakan yaitu menyusun instrumen penelitian berupa: Rencana Program Pembelajaran (RPP), Lembar Kegiatan Siswa (LKS), serta Lembar observasi. Merumuskan indikator berdasarkan: (1) Disiplin ilmu ekonomi: (a) Mendefinisikan kegiatan ekonomi, (b) Mendefinisikan pengerti produksi, (c) Mendefinisikan macam-macam sumber daya ekonomi, (d) Mendeskripsikan cara meningkatkan produksi, (e) Membuat produk model buku (buku kecil) dan menggunakan sumber daya yang dimiliki, (2) Disiplin ilmu geografi : (a) Mendefinisikan faktor produksi alam, (b) Mengidentifikasi aspek negatif limbah produksi bagi lingkungan hidup, (3) Disiplin ilmu sejarah : Mendeskripsikan perkembangan buku dari masa ke masa, (4) Disiplin ilmu sosiolog, (a) Mengidentifikasi dampak rasionalisasi, (b) Mengidentifikasi dampak positif kegiatan produksi bagi penduduk di sekitar perusahaan. Prosedur atau langkah-langkah penelitian yang dilakukan terbagi dalam bentuk siklus kegiatan, dimana setiap siklus terdiri atas empat kegiatan pokok yaitu kegiatan: perencanaan, tindakan pelaksanaan, pengamatan, dan refleksi. Empat kegiatan ini berlangsung secara simultan yang urutannya dapat mengalami modifikasi. Pada siklus I baik tindakan satu maupun tindakan dua, menemukan 
kelemahan kegiatan baik dari segi persiapan, waktu, proses kegiatan, hasil/penyelesaian dilanjutkan tindakan penekanan kepada peserta didik untuk memperbaikinya. Instrumen penelitian terdiri dari empat lembar berupa : (1) Data produktifitas untuk mengetahui jumlah buku yang diproduksi dalam tiga kali putaran, (2) Lembar penilaian aspek kognitif, (3) lembar penilaian aspek afektif, (4) Lembar penilaian aspek psikomotor dengan mengamati kemampuan melaksanakan praktek membuat buku, terdiri dari kegiatan persiapan, pelaksanaan dan hasil akhir.

Sintaks : (1) Melipat kemudian memotong kertas HVS folio menjadi delapan bagian sama lebar, (2) Menyusun dan dijadikan satu, lalu dilipat jadi dua seperti buku, (3) Menulis nomor urut halaman dimulai lembar kedua, cover depan dan belakang tidak diberi nomor halaman (terdapat 28 halaman), (4) Menulis judul dalam cover, dengan judul nama peserta didik atau nama kelompok, misal: Buku Tulis Siti Aisyah, Buku Tulis ABUCIDOS (Agung, Buamin, Cici, Dos Santos, dsb), (5) Memberi klip ditengah buku, (6) Menggabung buku yang sudah jadi dan mengikat dengan karet gelang. Putaran I melakukan praktek membuat buku tulis secara perorangan, tiap peserta didik membawa kertas HVS, pemes, klip, karet gelang. Putaran 2 membuat buku tulis secara kelompok (ada yang bagian melipat kertas, memotong kertas, menulis halaman dan cover serta mengikat dengan karet gelang dll). Putaran 3 mengganti posisi sesuai dengan keinginan peserta didik tetap per kelompok, bahan yang dipakai sama dengan putaran 2 . Memeriksa setiap buku tulis yang telah jadi dan menolak buku tulis yang belum jadi/ setengah jadi/ tidak layak jual. Jumlah buku tulis yang diterima dan memenuhi syarat ditulis peserta didik di lembar data produktifitas, kemudian peserta didik dipersilahkan menghitung nilai skor yang diperolehnya masing-masing.

Penelitian menggunakan teknik tes unjuk kerja untuk mengamati perbuatan peserta didik dengan menggunakan instrumen uji petik kerja prosedur dan produk. Tindakan direncanakan melalui dua siklus, siklus I putaran 1 setiap peserta didik melaksanakan semua tahapan membuat buku (10 menit), putaran 2 merupakan kerja kelompok dan spesialisasi tugas, satu peserta didik hanya menyelesaikan 1 bagian dari proses membuat buku (10 menit), putaran 3 merupakan tugas kelompok dan pergantian spesialisasi kerja (10 menit), dilanjutkan menemukan kelemahan tes baik dari segi waktu, persiapan bahan, proses pembuatan, hasil/penyelesaian dilanjutkan tindakan penekanan kepada peserta didik untuk memperbaikinya, serta menjelaskan buku yang sudah jadilah yang akan dinilai dengan asumsi bahwa buku yang memenuhi standar dan berkualitaslah yang mempunyai nilai jual dan layak dijual.

\section{HASIL DAN PEMBAHASAN}

Untuk menghitung data produktifitas menurut National Council on Economic Education (2003: n.p) yaitu jumlah barang dan jasa yang diproduksi (atau output) tiap satuan sumber daya produktif yang digunakan (atau input) dalam periode waktu tertentu, misalnya satu jam. Data produktifitas tersebut menggunakan tabel sbb.:

Tabel 1. Data produktifitas

Nama perusahaan Buku Tulis:

\begin{tabular}{|c|c|c|c|c|}
\hline & Contoh & $\begin{array}{l}\text { Putaran } \\
1\end{array}$ & $\begin{array}{l}\text { Putaran } \\
2\end{array}$ & \begin{tabular}{|l|} 
Putaran \\
3
\end{tabular} \\
\hline 1. Jumlah pekerja & 5 & & & \\
\hline $\begin{array}{l}\text { 2. Upah (tiap pekerja }= \\
\text { Rp.10) }\end{array}$ & Rp.50 & & & \\
\hline 3. Sewa pabrik (meja) & Rp.20 & $\begin{array}{r}\mathrm{Rp} .2 \\
0\end{array}$ & $\begin{array}{r}\mathrm{Rp} .2 \\
0\end{array}$ & $\begin{array}{r}\text { Rp. } 2 \\
0\end{array}$ \\
\hline $\begin{array}{l}\text { 4. Barang modal (jumlah } \\
\text { pulpen) }\end{array}$ & 1 & & & \\
\hline $\begin{array}{l}\text { 5. Investasi barang modal } \\
\text { (tiap pulpen }=\quad \text { Rp.5) }\end{array}$ & Rp.5 & & & \\
\hline $\begin{array}{l}\text { 6. Jumlah buku yang } \\
\text { diproduksi }\end{array}$ & 4 & & & \\
\hline $\begin{array}{l}\text { 7. Biaya bahan baku (tiap } \\
\text { buku yang diproduksi = } \\
\text { Rp. } 2,5 \text { ) }\end{array}$ & Rp.10 & & & \\
\hline $\begin{array}{l}\text { 8. Biaya total dari buku } \\
\text { yang diproduksi } \\
\text { Upah (baris } 2 \text { ) }+ \text { sewa } \\
\text { (baris } 3 \text { ) + investasi } \\
\text { barang modal (baris 5) } \\
+ \text { biaya bahan baku } \\
\text { (baris } 7 \text { ) }\end{array}$ & 5 & & & \\
\hline $\begin{array}{l}\text { 9. Biaya rata-rata dari tiap } \\
\text { buku yang diproduksi } \\
\text { Biaya total (baris 8) : } \\
\text { jumlah buku yang } \\
\text { diproduksi (baris 6) }\end{array}$ & Rp.21,25 & & & \\
\hline $\begin{array}{l}\text { 10.Produktifitas (Output } \\
\text { tiap pekerja dalam } \\
\text { waktu } 3 \text { menit) } \\
\text { Jumlah buku yang } \\
\text { diproduksi (baris 6) : } \\
\text { jumlah pekerja (baris } \\
\text { 1) }\end{array}$ & 0,8 & & & \\
\hline
\end{tabular}

Untuk mendapatkan nilai unjuk kerja penulis menggunakan tindakan atau tes praktik sesuai dengan yang dikemukakan Kunandar (2207:395) penilaian tindakan atau tes praktik secara efektif dapat digunakan untuk kepentingan pengumpulan berbagai informasi tentang bentuk-bentuk perilaku yang diharapkan muncul dalam diri siswa (ketrampilan). Penilaian perbuatan atau unjuk kerja merupakan penilaian yang dilakukan dengan mengamati kegiatan peserta didik dalam melakukan sesuatu. Menurut Direktorat Jendral pendidikan Dasar dan menengah, Direktorat Jendral pendidikan Guru dan Tenaga Teknis penilaian yang dilakukan dengan mengamati kegiatan peserta didik dalam melakukan sesuatu dengan mempertimbangkan: (1) Langkahlangkah kinerja yang dilakukan peserta didik, (2) Kelengkapan dan ketepatan aspek yang akan dinilai dalam kinerja tersebut, (3) Kemampuan-kemampuan 
khusus yang diperlukan untuk menyelesaikan tugas, (4) Upayakan kemampuan yang akan dinilai tidak terlalu banyak, sehingga semua dapat diamati, (5) Kemampuan yang akan dinilai diurutkan berdasarkan urutan yang akan diamati

\section{SIKLUS I}

Melakukan tindakan sesuai dengan yang sudah direncanakan, peserta didik melaksanakan tugas membuat buku tulis dengan rileks, menyenangkan tapi serius tanpa ada yang menyia-nyiakan waktu pada putaran 1 dan 2. Pada putaran 3 mengganti posisi spesialisasi kerja kepada peserta didik sesuai dengan keinginan dan kemampuannya di kelompok. Buku yang dihasilkan/diproduksi menggunakan skor sbb.:

Tabel 2. Pedoman skor buku yang diproduksi siklus I

\begin{tabular}{|c|c|}
\hline Buku yang Produksi & Skor \\
\hline 1 & 0,5 \\
\hline 2 & 1,0 \\
\hline 3 & 1,5 \\
\hline 4 & 2,0 \\
\hline 5 & 2,5 \\
\hline 6 & 3,0 \\
\hline 7 & 3,5 \\
\hline 8 & 4,0 \\
\hline
\end{tabular}

Memeriksa setiap buku tulis yang telah jadi dan menolak buku tulis yang belum jadi/ setengah jadi/ tidak layak jual dengan jumlah 35 buku tulis. Jumlah buku tulis yang diterima dan memenuhi syarat ditulis peserta didik di lembar data produktifitas. Kemudian peserta didik dipersilahkan menghitung nilai skor yang diperolehnya masing-masing.

Tabel 3. Hasil skor putaran 1, 2, 3 siklus I

\begin{tabular}{|c|c|c|c|}
\hline \multirow{2}{*}{ Skor } & \multicolumn{3}{|c|}{ Jumlah Peserta Didik } \\
\cline { 2 - 4 } & Putaran 1 & Putaran 2 & Putaran 3 \\
\hline 2,0 & 1 & 0 & 0 \\
\hline 2,5 & 9 & 0 & 0 \\
\hline 3,0 & 15 & 13 & 0 \\
\hline 3,5 & 10 & 5 & 0 \\
\hline 4,0 & 3 & 8 & 9 \\
\hline 4,5 & 0 & 4 & 9 \\
\hline 5,0 & 0 & 8 & 20 \\
\hline Jumlah & 38 & 38 & 38 \\
\hline
\end{tabular}

Terjadi kenaikan skor yang diperoleh dari putaran 1 ke putaran 2, dan 3 menunjukkan adanya kenaikan jumlah buku yang dibuat/diproduksi, hal ini sesuai dengan yang dikemukakan National Council on Economics Education (2003: n.p) memproduksi lebih banyak barang dan jasa dengan jumlah sumber daya yang sama, atau dengan memproduksi jumlah barang dan jasa yang sama dengan sumber daya yang lebih sedikit.

Kemudian peserta didik dipersilahkan menghitung sendiri nilainya dengan rumus:
Skor yang diperoleh

Nilai $=\longrightarrow 100$

15

Hasil rekapitulasi nilai aspek koqnitif, afektif, buku yang diproduksi, serta aspek psikomotor sbb.:

Tabel 4. Rekapitulasi nilai aspek kognitif, afektif, produktifitas, psikomotor Siklus I

\begin{tabular}{|c|c|c|c|c|c|}
\hline \multirow{2}{*}{$\begin{array}{c}\text { No } \\
\text { urut } \\
\text { siswa }\end{array}$} & \multicolumn{4}{|c|}{ Nilai } & \multirow[b]{2}{*}{ Nilai } \\
\hline & Koqnitif & Afektif & $\begin{array}{c}\text { Produktif } \\
\text { itas }\end{array}$ & $\begin{array}{l}\text { Psikom } \\
\text { otor }\end{array}$ & \\
\hline 1 & 60 & 76 & 63 & 60 & 65 \\
\hline 2 & 60 & 76 & 73 & 64 & 68 \\
\hline 3 & 80 & 80 & 67 & 64 & 73 \\
\hline 4 & 60 & 80 & 67 & 73 & 70 \\
\hline 5 & 75 & 84 & 80 & 64 & 76 \\
\hline 6 & 75 & 76 & 83 & 73 & 77 \\
\hline 7 & 70 & 76 & 80 & 73 & 75 \\
\hline 8 & 80 & 76 & 80 & 73 & 77 \\
\hline 9 & 75 & 76 & 77 & 65 & 73 \\
\hline 10 & 80 & 80 & 73 & 67 & 75 \\
\hline 11 & 65 & 72 & 77 & 58 & 68 \\
\hline 12 & 80 & 76 & 73 & 45 & 69 \\
\hline 13 & 80 & 76 & 80 & 73 & 77 \\
\hline 14 & 70 & 80 & 80 & 64 & 74 \\
\hline 15 & 80 & 80 & 80 & 69 & 77 \\
\hline 16 & 75 & 68 & 80 & 65 & 72 \\
\hline 17 & 70 & 72 & 90 & 65 & 74 \\
\hline 18 & 80 & 72 & 90 & 64 & 77 \\
\hline 19 & 80 & 80 & 87 & 60 & 77 \\
\hline 20 & 75 & 80 & 80 & 65 & 75 \\
\hline 21 & 70 & 76 & 87 & 65 & 75 \\
\hline 22 & 65 & 80 & 83 & 65 & 73 \\
\hline 23 & 65 & 68 & 87 & 67 & 72 \\
\hline 24 & 85 & 68 & 87 & 69 & 77 \\
\hline 25 & 90 & 80 & 77 & 64 & 78 \\
\hline 26 & 60 & 68 & 73 & 73 & 69 \\
\hline 27 & 70 & 84 & 80 & 67 & 75 \\
\hline 28 & 80 & 76 & 80 & 73 & 77 \\
\hline 29 & 85 & 76 & 70 & 64 & 74 \\
\hline 30 & 70 & 80 & 70 & 73 & 73 \\
\hline 31 & 70 & 72 & 67 & 65 & 69 \\
\hline 32 & 65 & 80 & 70 & 60 & 69 \\
\hline 33 & 80 & 84 & 67 & 73 & 76 \\
\hline 34 & 70 & 76 & 73 & 62 & 70 \\
\hline 35 & 60 & 72 & 67 & 65 & 66 \\
\hline 36 & 70 & 88 & 70 & 65 & 73 \\
\hline 37 & 80 & 76 & 73 & 60 & 67 \\
\hline 38 & 70 & 76 & 63 & 71 & 70 \\
\hline $\mathrm{Rt} 2$ & 72,5 & 76,7 & 76,4 & 65,9 & 72,9 \\
\hline
\end{tabular}

Dari rekapitulasi nilai aspek kognitif, afektif, produktifitas, psikomotor Siklus I mendapatkan hasil ratarata sbb.:

Tabel 5. Prosentase dan nlai rata-rata siklus I

\begin{tabular}{|c|c|c|c|}
\hline Nilai & $\begin{array}{c}\text { Jumlah } \\
\text { Siswa }\end{array}$ & Prosentase & $\begin{array}{c}\text { Rata- } \\
\text { rata }\end{array}$ \\
\hline 78 & 1 & 2,63 & \\
\hline 77 & 8 & 22,05 & \\
\hline 76 & 2 & 5,26 & \\
\hline 75 & 5 & 13,17 & \\
\hline 74 & 3 & 7,89 & \\
\hline 73 & 5 & 13,17 & \\
\hline 72 & 2 & 5,26 & 72,95 \\
\hline
\end{tabular}




\begin{tabular}{|c|c|c|c|}
\hline Nilai & $\begin{array}{c}\text { Jumlah } \\
\text { Siswa }\end{array}$ & Prosentase & $\begin{array}{c}\text { Rata- } \\
\text { rata }\end{array}$ \\
\hline 70 & 3 & 7,89 & \\
\hline 69 & 4 & 10,53 & \\
\hline 68 & 2 & 5,26 & \\
\hline 67 & 1 & 2,63 & \\
\hline 66 & 1 & 2,63 & \\
\hline 65 & 1 & 2,63 & \\
\hline Jumlah & 38 & 100 & \\
\hline
\end{tabular}

Semua peserta didik mendapatkan nilai sangat tinggi baik aspek kognitif, afektif maupun psikomotor, walaupun ada satu peserta didik yang mendapat nilai sama dengan KKM (65). Pada waktu memotong kertas ada lima kelompok yang menggunakan pemes lebih dari satu, dan empat kelompok menggunakan bolpoin lebih dari satu.

Untuk lebih mengetahui tingkat kemampuan peserta didik pada topik produktifitas, maka dilakukan tindakan kembali pada siklus II.

\section{SIKLUS II}

Membagi peserta didik menjadi sembilan kelompok dengan pembagian menurut nomor absen ganjil dan genap, tujuh kelompok terdiri dari empat peserta didik, dua kelompok terdiri dari lima peserta didik. Peneliti memberi penekanan kepada peserta didik, agar melaksanakan kegiatan sesuai dengan petunjuk dan tidak melewati batas waktu yang telah ditentukan, serta pada putaran 2 dan 3 dilarang menambah barang modal pemes (untuk membantu memotong kertas), tetapi menambah barang modal bolpoin menjadi dua. Sesuai yang dikemukakan oleh Yudhistira (2006: 48-49) cara meningkatkan produktifitas yaitu dengan cara: (1) Intensifikasi yaitu usaha meningkatkan hasil produksi dengan cara meningkatkan kemampuan atau memaksimalkan produktifitas faktor-faktor produksi yang telah ada, (2) Ekstensifikasi yaitu meningkatkan hasil produksi dengan cara menambah dan atau memperluas faktor-faktor produksi yang digunakan. Sehingga penulis menaikkan skor buku tulis yang dihasilkan (diproduksi) pada putaran 3 siklus II dengan berpedoman pada tabel 6 .

Tabel 6. Pedoman skor buku yang diproduksi siklus II

\begin{tabular}{|c|c|}
\hline Buku yang Produksi & Skor \\
\hline 1 & 0,3 \\
\hline 2 & 0,5 \\
\hline 3 & 0,8 \\
\hline 4 & 1,0 \\
\hline 5 & 1,3 \\
\hline 6 & 1,5 \\
\hline 7 & 1,8 \\
\hline 8 & 2,0 \\
\hline
\end{tabular}

Peserta didik melaksanakan tindakan membuat buku tulis dengan baik dan lancar karena sudah berpengalaman pada siklus I. Peneliti memberi teguran keras bagi yang melanggar aturan permainan karena satu kelompok menambah lagi barang modal (bolpoin), dan satu kelompok membantu menulis judul dalam cover.

Menerima setiap buku tulis yang telah selesai dan menolak buku tulis yang belum jadi atau setengah jadi/tidak layak jual berjumlah 14 buku tulis. Jumlah buku tulis yang diterima dan memenuhi syarat ditulis peserta didik di lembar data produktifitas dan dipersilahkan menghitung sendiri nilainya dengan berpedoman sesuai dengan siklus I, hasil perhitungan sbb.:

Tabel 7. Hasil skor putaran 1, 2, 3 siklus II

\begin{tabular}{|c|c|c|c|}
\hline \multirow{2}{*}{ Skor } & \multicolumn{3}{|c|}{ Jumlah Peserta Didik } \\
\cline { 2 - 4 } & Putaran 1 & Putaran 2 & Putaran 3 \\
\hline 2,0 & 0 & 0 & 0 \\
\hline 2,5 & 0 & 0 & 8 \\
\hline 2,8 & 0 & 0 & 4 \\
\hline 3,0 & 0 & 0 & 4 \\
\hline 3,3 & 0 & 0 & 5 \\
\hline 3,5 & 8 & 0 & 4 \\
\hline 3,8 & 0 & 0 & 4 \\
\hline 4,0 & 15 & 25 & 9 \\
\hline 4,5 & 15 & 8 & 0 \\
\hline 5,0 & 0 & 5 & 0 \\
\hline Jumlah & 38 & 38 & 38 \\
\hline
\end{tabular}

Tabel 8. Rekapitulasi nilai aspek koqnitif, afektif, buku yang diproduksi, serta aspek psikomotor II

\begin{tabular}{|c|c|c|c|c|c|}
\hline \multirow{2}{*}{$\begin{array}{c}\text { No } \\
\text { Urut } \\
\text { Siswa }\end{array}$} & \multicolumn{4}{|c|}{ Nilai } & \multirow[b]{2}{*}{ Nilai } \\
\hline & Koqnitif & Afektif & Produktifitas & Psikomotor & \\
\hline 1 & 90 & 88 & 70 & 75 & 81 \\
\hline 2 & 100 & 88 & 70 & 73 & 83 \\
\hline 3 & 80 & 84 & 73 & 69 & 77 \\
\hline 4 & 75 & 76 & 70 & 73 & 74 \\
\hline 5 & 80 & 72 & 70 & 69 & 73 \\
\hline 6 & 80 & 80 & 70 & 73 & 76 \\
\hline 7 & 75 & 72 & 67 & 82 & 74 \\
\hline 8 & 90 & 76 & 70 & 78 & 79 \\
\hline 9 & 80 & 80 & 75 & 69 & 76 \\
\hline 10 & 85 & 80 & 80 & 67 & 78 \\
\hline 11 & 75 & 88 & 78 & 75 & 79 \\
\hline 12 & 100 & 76 & 73 & 67 & 79 \\
\hline 13 & 95 & 80 & 72 & 73 & 80 \\
\hline 14 & 90 & 80 & 73 & 73 & 79 \\
\hline 15 & 95 & 76 & 72 & 71 & 79 \\
\hline 16 & 90 & 72 & 73 & 78 & 78 \\
\hline 17 & 85 & 76 & 83 & 82 & 82 \\
\hline 18 & 85 & 80 & 77 & 82 & 81 \\
\hline 19 & 85 & 84 & 83 & 89 & 85 \\
\hline 20 & 100 & 84 & 73 & 84 & 85 \\
\hline 21 & 95 & 80 & 80 & 89 & 86 \\
\hline 22 & 100 & 72 & 70 & 89 & 83 \\
\hline 23 & 65 & 76 & 77 & 71 & 72 \\
\hline 24 & 85 & 76 & 73 & 82 & 79 \\
\hline 25 & 90 & 72 & 85 & 71 & 80 \\
\hline 26 & 60 & 68 & 87 & 75 & 73 \\
\hline
\end{tabular}




\begin{tabular}{|c|c|c|c|c|c|}
\hline $\begin{array}{c}\text { No } \\
\text { Urut } \\
\text { Siswa }\end{array}$ & \multicolumn{4}{|c|}{ Nilai } & \multirow{2}{*}{ Nilai } \\
\cline { 2 - 5 } & Koqnitif & Afektif & Produktifitas & Psikomotor & \\
\hline 27 & 70 & 80 & 82 & 75 & 77 \\
\hline 28 & 80 & 84 & 87 & 69 & 80 \\
\hline 29 & 85 & 76 & 82 & 75 & 80 \\
\hline 30 & 70 & 84 & 90 & 78 & 81 \\
\hline 31 & 100 & 76 & 85 & 78 & 85 \\
\hline 32 & 90 & 84 & 90 & 80 & 86 \\
\hline 33 & 80 & 84 & 75 & 82 & 80 \\
\hline 34 & 70 & 76 & 90 & 73 & 77 \\
\hline 35 & 85 & 80 & 78 & 78 & 80 \\
\hline 36 & 75 & 84 & 78 & 65 & 76 \\
\hline 37 & 95 & 72 & 78 & 71 & 79 \\
\hline 38 & 75 & 80 & 78 & 78 & 78 \\
\hline rt2 & 84,3 & 78,8 & 77,3 & 75,7 & 79,0 \\
\hline
\end{tabular}

Tabel 9. Prosentase dan nilai rata-rata siklus II

\begin{tabular}{|c|c|c|c|}
\hline Nilai & $\begin{array}{c}\text { Jumlah } \\
\text { Siswa }\end{array}$ & Prosentase & Rata-rata \\
\hline 86 & 2 & 5,26 & \\
\hline 85 & 3 & 7,89 & \\
\hline 83 & 2 & 5,26 & \\
\hline 82 & 1 & 2,63 & \\
\hline 81 & 3 & 7,89 & \\
\hline 80 & 6 & 15,81 & \\
\hline 79 & 7 & 18,44 & 79,21 \\
\hline 78 & 3 & 7,89 & \\
\hline 77 & 3 & 7,89 & \\
\hline 76 & 3 & 7,89 & \\
\hline 74 & 2 & 5,26 & \\
\hline 73 & 2 & 5,26 & \\
\hline 72 & 1 & 2,63 & \\
\hline Jumlah & 38 & 100 & \\
\hline
\end{tabular}

\section{Refleksi dan Temuan}

Dengan menambah barang modal bolpoin dari satu menjadi dua mengakibatkan hasil produktifitas meningkat walaupun skor dirubah. Semua peserta didik mendapatkan nilai sangat tinggi baik aspek kognitif, afektif maupun psikomotor, walaupun ada satu peserta didik yang mendapat nilai sama dengan KKM (65). Pada waktu memotong kertas ada lima kelompok yang menggunakan pemes lebih dari satu, dan empat kelompok menggunakan bolpoin/lebih dari satu. Dapat disimpulkan bahwa penilaian unjuk kerja merupakan model pembelajaran yang mengakomodasi tujuan proses dalam pembelajaran, menuntut peserta didik melakukan tugas dalam bentuk perbuatan yang dapat diamati oleh guru, sehingga membuat pelajaran lebih relevan dengan dunia nyata dan bermakna.

Setelah berakhir proses pembelajaran, peneliti memberikan kesempatan kepada peserta didik untuk merenung atau mengingat kembali apa yang telah dikerjakannya, dan membiarkan secara bebas menafsirkan pengalamannya sendiri, sehingga peserta didik dapat menyimpulkan tentang pengalaman belajarnya. Dari hasil pengalaman belajar peserta didik jelaslah bahwa segi pengelolaan maupun segi proses pendidikan dapat mengarahkan secara efektif dan meningkatkan nilai tambah faktor-faktor peserta didik untuk menghasilkan prestasi belajar setinggi-tingginya.

\section{PENUTUP}

\section{Simpulan}

Penelitian tindakan kelas tentang peningkatan prestasi/nilai peserta didik mata pelajaran IPS topik produktifitas melalui teknik tes unjuk kerja telah dilaksanakan dalam dua siklus kegiatan, menghasilkan kesimpulan, (1) Melalui teknik tes unjuk kerja, dapat meningkatkan kemampuan peserta didik dalam menguasai mata pelajaran IPS, topik produktifitas, (2) Prestasi peserta didik setelah mengalami 2 siklus tetap tinggi, walaupun dilakukan perubahan spesialisasi kerja, serta merubah skor dari hasil produksi dibagi 2 menjadi hasil produksi dibagi 4 pada putaran 3 siklus II. Siklus I ratarata nilai peserta didik 72,95 , sedangkan pada siklus II rata-rata 79,21 , ada kenaikan senilai 6,26 atau $8,58 \%$ berarti terjadi peningkatan prestasi/nilai diatas siklus I, (3) Faktor-faktor yang mempengaruhi pelaksanaan pembelajaran dalam rangka peningkatan kemampuan peserta didik pada topik produktifitas adalah: (a) Faktor peserta didik: Ada peserta didik yang tidak mempersiapkan lebih dahulu bahan yang harus dibawanya, tetapi meminta kepada peserta didik yang lain sehingga mempengaruhi nilai skor yang diterimanya, ada rasa setia kawan diantara peserta didik sehingga membantu teman dalam memotong kertas dan menulis nomor halaman serta memberi judul pada cover, kurangnya kecepatan dalam membuat buku tulis, karena masih ada buku tulis yang tidak layak jual. (b) Faktor guru: Dituntut kecepatan dan ketelitian dalam mensortir buku tulis hasil produksi, dituntut mampu mengawasi kegiatan setiap putaran baik putaran 1,2 dan 3 dari 38 peserta didk dalam waktu bersamaan dan runtut, (c) Faktor waktu: Kurangnya waktu. Sehingga pada saat menjelaskan konsep produktifitas dilakukan dengan tergesa-gesa, supaya waktu yang tersisa cukup untuk praktek membuat buku, (4) Hipotesa teknik tes unjuk kerja dapat meningkatkan prestasi/ nilai peserta didik mata pelajaran IPS topik produktifitas dapat diterima.

\section{Saran}

Adapun saran dari penelitian ini, agar nilai lebih obyektif sebaiknya, (1) Bagi peserta didik: (a) jangan sampai lupa membawa bahan yang diperintahkan, sehingga tidak mempengaruhi hasil nilai yang diperoleh, (b) Dalam membuat buku tulis dilarang membantu, walaupun satu kelompok, (c) Mampu mengurangi jumlah buku tulis yang tidak layak jual dengan cara bekerja lebih cepat, baik dan teliti, (d) Dilarang berbuat curang atau 
melanggar aturan main yang telah disepakati bersama. (2) Bagi Guru: (a) Diperlukan konsentrasi tinggi supaya cepat dan teliti dalam mensortir buku tulis hasil produksi, (b) Diperlukan stamina yang prima karena mengawasi setiap kegiatan 38 peserta didik sekaligus secara bersamaan dan runtut dalam waktu 10 menit setiap kali putaran, (c) Materi yang essensial dan relevan saja yang perlu dibahas pada KBM supaya tidak kekurangan waktu.

\section{DAFTAR PUSTAKA}

Depdikbud. Direktorat Jendral; Pendidikan Dasar dan Menengah. Direktorat Jendral Pendidikan Guru dan Tenaga Teknis. Sistem Penilaian Proses Berbasis Kelas. Makalah disajikan pada workshop kolaborasi pengembangan kurikulum tingkat satuan pendidikan (KTSP). (Photocopian). Wisma Guru, Surabaya, 17 sd 19 Pebruari 2007. Jakarta: Proyek peningkatan mutu tenaga kependidikan Dikdasmen.

Idris, Zahara \& JamaL, Lisma. 1992. Pengantar Pendidikan I. Jakarta: Gramedia Widiasarana Indonesia.

Kardiman, dkk. 2006. Ekonomi Dunia Keseharian Kita I. Bogor: Yudhistira

Kosim. 2000. Ilmu Pengetahuan Sosial Ekonomi SLTP I. Bandung: Grafindo Media Pratama

Kunandar. 2007, Guru Profesional, Implementasi Kurikulum Tingkat Satuan Pendidikan (KTSP) dan Sukses dalam Sertifikasi Guru, Jakarta: Raja Grafindo Persada.

Mulyasa, E. 2009. Praktik Penelitian Tindakan Kelas. Bandung: PT Remaja Rosdakarya Offset

National Council on Economics Education. 2003. Economics in Actions. New York, New York, AS (Penerjemah: UNESA, Photocopian). Makalah disajikan pada temu muka MGMP Pengetahuan Sosial-Ekonomi di SMPN 2 Surabaya, 2006

Peraturan Pemerintah Republik Indonesia Nomor 19 Tahun 2005 T.Th. Tentang Standar Nasional Pendidikan. Jakarta: Cemerlang

Subroto, Wahyuni. 2004. Pengetahuan Sosial Ekonomi I. Jakarta: Sinar Grafika Offset

Suryadi, Ace. September 1993. Kebijakan Pendidikan Suatu Pengantar. Bandung: PT Remaja Rosda Karya.

Udin Saefudin Sa'ud, 2008, Inovasi pendidikan, Bandung: Alfabeta 